Article

\title{
Numerical Climatic Analysis of Soybean Development in Sowing Dates in Humid Subtropical Climate
}

\author{
Mateus Possebon Bortoluzzi ${ }^{1}$ (D), Arno Bernardo Heldwein ${ }^{2}$ (D), Roberto Trentin ${ }^{3}$ (D), \\ Ivan Carlos Maldaner ${ }^{4}$ (D) Jocélia Rosa da Silva ${ }^{2}$ (D), Astor Henrique Nied ${ }^{2}$ \\ ${ }^{1}$ Faculdade de Agronomia e Medicina Veterinária, Universidade de Passo Fundo, Passo Fundo, \\ RS, Brasil. \\ ${ }^{2}$ Departamento de Fitotecnia, Universidade Federal de Santa Maria, Santa Maria, RS, Brasil. \\ ${ }^{3}$ Departmento de Fitotecnia, Universidade Federal de Pelotas, Capão do Leão, RS, Brasil. \\ ${ }^{4}$ Instituto Federal Farroupilha, São Vicente do Sul, RS, Brasil.
}

Received: 1 October 2020 - Accepted: 4 February 2021

\begin{abstract}
The objective of this study was to determine the mean duration and the interannual variability of phenological subperiods and total soybean development cycle for 11 sowing dates in the humid subtropical climate conditions of the state of Rio Grande do Sul. Daily meteorological data were used from 1971 to 2017 obtained from the Pelotas agroclimatological station and from 1968 to 2017 from the main climatological station of Santa Maria. The soybean development simulation was performed considering three sets of cultivars of relative maturity groups between 5.9-6.8, 6.9-7.3 and 7.4-8.0, with intervals between the sowing dates of approximately 10 days, comprising September, 21 to December, 31. The data of phenological subperiods duration and total development cycle were subjected to the exploratory analysis BoxPlot, analysis of variance and mean comparison by the Scott-Knott test, with $5 \%$ of probability. The development cycle duration is greater in Pelotas than in Santa Maria. There was a decrease in soybean cycle duration from the first to the last sowing date for both locations. The R1-R5 subperiod duration is decreasing from October to December due to photoperiod reduction.
\end{abstract}

Keywords: Glycine max, thermal time, photoperiod, modeling, phenology.

\section{Análise Numérica Climática do Desenvolvimento da Soja em Datas de Semeadura em Clima Subtropical Úmido}

\begin{abstract}
Resumo
O objetivo desse estudo foi determinar a duração média e a variabilidade interanual dos subperíodos fenológicos e do ciclo total de desenvolvimento da soja para 11 datas de semeadura em condições de clima subtropical úmido do estado do Rio Grande do Sul. Foram utilizados dados meteorológicos diários de 1971 a 2017 da estação agroclimatológica de Pelotas e de 1968 a 2017 da estação climatológica principal de Santa Maria. A simulação do desenvolvimento da soja foi realizada considerando-se três conjuntos de cultivares de grupo de maturidade relativa entre 5.9-6.8, 6.9-7.3 e 7.48.0, com intervalos entre as datas de semeadura de aproximadamente 10 dias compreendidas entre 21 de setembro e 31 de dezembro. Os dados de duração dos subperíodos fenológicos e do ciclo total de desenvolvimento foram submetidos à análise exploratória BoxPlot, análise de variância e comparação de médias pelo teste de Scott-Knott, a 5\% de probabilidade. A duração do ciclo de desenvolvimento é maior em Pelotas do que em Santa Maria. Houve decréscimo da duração do ciclo da soja da primeira para a última data de semeadura para ambos os locais. Devido à redução do fotoperíodo, a duração do subperíodo R1-R5 é decrescente de outubro até dezembro.
\end{abstract}

Palavras-chave: Glycine max, soma térmica, fotoperíodo, modelagem, fenologia.

Corresponding author: Mateus Possebon Bortoluzzi, mateusbortoluzzi@upf.br. 


\section{Introduction}

Soybean is the most important aleuro-oleaginous crop in the world, being the crop with the largest area sown in Brazil $\left(36.8 \times 10^{6}\right.$ ha) during the 2019/2020 agricultural crop. In Rio Grande do Sul, the third largest Brazilian producer state, 5.9 million hectares were cultivated, with an average yield of $3.15 \mathrm{tha}^{-1}$ in this agricultural year (CONAB, 2020). Despite the technological advance in the soybean production system, the yield difference between years is significant, which is directly related to the interannual and spatial variability of the meteorological conditions.

The main abiotic factors that influence soybean crop development are air temperature and photoperiod. The first contributes positively to plant development, whereas higher than the lower base temperature and below the upper base temperature (Setiyono et al., 2007). Considering that soybean is a short-day plant, reduced development rate occurs when the plants are subjected to longer photoperiod conditions. Thus, increased development cycle is expected in regions more distant from the equator line, but also alterations in function of sowing date, as well as the thermal time variability among years.

The use of crop development simulation models associated with probability analysis enables the characterization of data distribution of a given variable and production risks. Among the models that can be used to simulate soybean plant development are the models proposed by Sinclair (1986) and Setiyono et al. (2007). However, these models require specific information on cultivars or relative maturity groups that are not yet available for the most recent indeterminate growth cultivars in Brazil. The SoySim model (Setiyono et al., 2010) was developed using cultivars of the relative maturity groups (RMG) between 0.8 and 4.2 in U.S. temperate conditions. Cera et al. (2017) verified an unsatisfactory performance of this model for low latitude conditions in Brazil using RMG cultivars 4.8 to 8.2 and warned to the problems of its use under Brazilian conditions.

Trentin et al. (2016) utilized a combination of different development models to estimate the soybean stages of emergence, first trifoliate leaf emission (V2), beginning of flowering (R1), beginning of grain filling (R5), physiological maturity (R7), and harvest maturity (R8). The time of occurrence of these stages practically does not vary as a function of soybean growth habit (Zanon et al., 2018). Therefore, we can infer that this methodology is an excellent alternative, considering the use of parameters and coefficients obtained in Rio Grande do Sul state. Furthermore, the methodology proposed by Trentin et al. (2016) has already been used to adjust probability functions to water excess and deficit (Bortoluzzi et al., 2020a) and to determine the risk of occurrence of water deficit in soybean cultivated in lowland soils (Bortoluzzi et al., 2020b).
In this context, the objective of this study was to determine the mean duration and the interannual variability of phenological subperiods and total soybean development cycle for 11 sowing dates in the humid subtropical climate conditions of the state of Rio Grande do Sul.

\section{Material and Methods}

Daily meteorological data of maximum air temperature $\left(\mathrm{Tx},{ }^{\circ} \mathrm{C}\right)$, minimum air temperature $\left(\mathrm{Tn},{ }^{\circ} \mathrm{C}\right)$ and insolation (hours) were collected at Pelotas agroclimatological station located in the county of Capão do Leão, RS, southern Brazil ( $31^{\circ} 52^{\prime}, \mathrm{S}, 52^{\circ} 21^{\prime} \mathrm{W}$ at $13.2 \mathrm{~m}$ altitude), from September 1971 to June 2017 and at the main climatological station of Santa Maria, RS, Brazil $\left(29^{\circ} 43^{\prime} 23^{\prime \prime}\right.$ S, $53^{\circ} 43^{\prime} 15^{\prime \prime} \mathrm{W}$, at $95 \mathrm{~m}$ altitude), from September 1968 to June 2017, which totalized 46 and 49 years of observations, respectively. The daily photoperiod for Pelotas and Santa Maria was calculated according to Kiesling (1982), considering the duration of the civil twilight of $6^{\circ}$ below the horizon plane. According to the Köppen climate classification, the climate of the region is subtropical humid Cfa (Alvares et al., 2013).

For the development simulation, three sets composed of cultivars of relative maturity groups (RMG) between 5.9-6.8, 6.9-7.3 and 7.4-8.0 were considered. Intervals between sowing dates (SD) of 10 or 11 days were taken during the sowing period from September 21 to December 31 .

The study and calculations were performed according to the methodology proposed by Trentin et al. (2013). Calculation of thermal time was used to estimate the emergence date, and the cumulative value of $92.5^{\circ} \mathrm{C}$ day was adopted, beginning from the base temperature of $10{ }^{\circ} \mathrm{C}$ (Schneider et al., 1987) and using the daily mean air temperature $(\mathrm{T})$, which was obtained from the arithmetic mean of Tx and Tn temperatures. Occurrence date of the first trifoliate leaf emission stage (V2) was estimated using the Soydev model (Setiyono et al., 2007), using coefficients obtained by Streck et al. (2009).

The beginning of flowering (R1) date was simulated with the non-linear model of development response to air temperature and with photoperiod proposed by Sinclair et al. (1991), using different coefficients according to the maturity group. The occurrence date of beginning of grain filling (R5) was estimated by the model proposed by Sinclair et al. (2007), using linear regression based on photoperiod and variable coefficients according to the maturity group.

The date of physiological maturity (R7) stage was simulated from the date of R5 stage occurrence by calculating the thermal time and adopting the base temperature of $10^{\circ} \mathrm{C}$ and the accumulated thermal time of $554^{\circ} \mathrm{C}$ day (Martorano et al., 2012). The date of harvest maturity (R8) was simulated by the model proposed by Sinclair (1986), 
without the water deficit response function in the algorithm and the plastochron values obtained by Streck et al. (2008). For using the Sinclair model (1986), the flux density of incident global solar radiation $(\mathrm{Rg})$ was required to be estimated by means of the Ångström Prescott equation with adjusted monthly coefficients for Santa Maria (Buriol et al., 2012 ) and for Pelotas (Steinmetz and Assis, 1999).

The data of phenological subperiods duration and total development cycle were submitted to the exploratory analysis BoxPlot, analysis of variance and mean comparison by the Scott and Knott (1974) test with 5\% of probability, considering the sowing dates as a source of variation.

\section{Results and Discussion}

The mean values of development cycle duration of the three relative maturity groups (RMG: 5.9-6.8; 6.9-7.3; 7.4-8.0) decreased among all 11 sowing dates, except by RMG 7.4-8.0 for Santa Maria in which there was a shorter duration for sowing in September than in October (Fig. 1). There was a total reduction of $28 \%$ and $24 \%$ between the first (September 21) and the last (December 31) sowing date respectively for Santa Maria (Figs. 1A, C and E) and Pelotas (Figs. 1B, D and F). This is mainly due to the gradual increase in air temperature from September to January, increasing the daily thermal time, in addition to the greater photoperiodic induction to flowering at later sowing dates, which mainly affects the V2-R1 and R1-R5 subperiod(s), as demonstrated by Sinclair et al. (1991) and Sinclair et al. (2007).

Zanon et al. (2018) presented mean values of soybean development cycle duration in Rio Grande do Sul for different RMG and sowing dates. In general, the values obtained in this study for Pelotas were quite similar independently of RMG, especially considering the sowing dates in November and December. However, there was a trend of underestimation of the simulated data in Pelotas of approximately 10 days for the sowing dates performed in October. For RMG 7.4-8.0, there were small differences in cycle duration between Santa Maria and Pelotas for sowing dates performed in November and December (Fig. 1), as well as in relation to data obtained by Zanon et al. (2018). For RMG 5.9-6.8 and 6.9-7.3, the data obtained in Santa Maria presented a maximum difference of 11 days in sowing dates performed in November and December and a lower performance in October, with a difference of up to 23 days.

The difference in cycle duration between the three soybean RMG was lower in the first sowing dates (Sept/21 to Oct/21), with RMG 7.4-8.0 presenting the longest cycle (Fig. 1). This result was expected given that in the same region, the greater the RMG, the longer the development cycle of a cultivar (Zanon et al., 2018). There was also a greater amplitude between the first and third quartiles of the exploratory BoxPlot analysis in the first sowing dates (Fig. 1). This occurred due to the variable thermal conditions between the years in October, mainly influencing the duration of the initial subperiods of soybean development.

Information related to the amplitude of historical duration of the soybean cycle can be obtained by observing the extreme values (outliers). For instance, minimum and maximum cycle duration obtained for RMG 5.9-6.3 and 6.3-7.4 was respectively of 115 and 154 days for sowing on September 21 in Santa Maria (Fig. 1A and 1C). For RMG 7.4-8.0, the cycle duration was between 119 and 159 days for all studied years in Santa Maria (Fig. 1E). This interpretation of extreme values can be used for all sowing dates and RMG for both studied locations.

The latitude effect was evidenced when comparing the cycle durations for Santa Maria (Figs. 1A, 1C and 1E) and Pelotas (Figs. 1B, 1D and 1F). Longer development cycle duration was observed in Pelotas, with a decreasing difference between locations throughout the sowing calendar. This smaller difference occurred due to lower flowering induction by the longer photoperiod near the Summer solstice along with lower thermal availability for Pelotas, which presents mean air temperature of $1.2{ }^{\circ} \mathrm{C}$ lower than Santa Maria, considering the datasets of both locations.

The S-E subperiod exhibited longer duration in the first sowing dates due to lower air temperature in the growing environment. In simulated sowing up to October 21, a subperiod duration was found between 8 and 11 days for Santa Maria (Figs. 2, 3 and 4) and between 9 and 13 days for Pelotas (Figs. 5, 6 and 7) due to the greater thermal availability in Santa Maria.

Regardless of RMG, the subperiod emergence (EM) until the first trifoliate leaf emission (V2) presented reduced mean duration throughout the sowing window, mainly due to increased thermal availability, resulting in a longer subperiod duration for Pelotas. Moreover, a smaller interquartile range was found for the last sowing dates, indicating that the variability between years also decreased. This trend was observed for all RMG and the duration of this subperiod was slightly greater for RMG 7.4-8.0 (Figs. 4 and 7).

In addition to the air temperature effect, photoperiod had a prominent effect on flowering induction for the V2R1 subperiod. Moreover, the first sowing dates (until Oct/ 11) presented a shorter duration, especially for larger RMG cultivars. These results are corroborated by the results obtained by Zanon et al. (2015) in sowings performed outside the recommended period (September, January and February). These authors verified decreased vegetative phase duration due to exposure to shorter photoperiods, mainly in determinate growth habit cultivars, especially in older cultivars that did not yet have the juvenility gene (Carpentieri-Pípolo et al., 2002).

Soybean growth and development is closely linked to cultivar growth habit and sowing date. In recent years, 

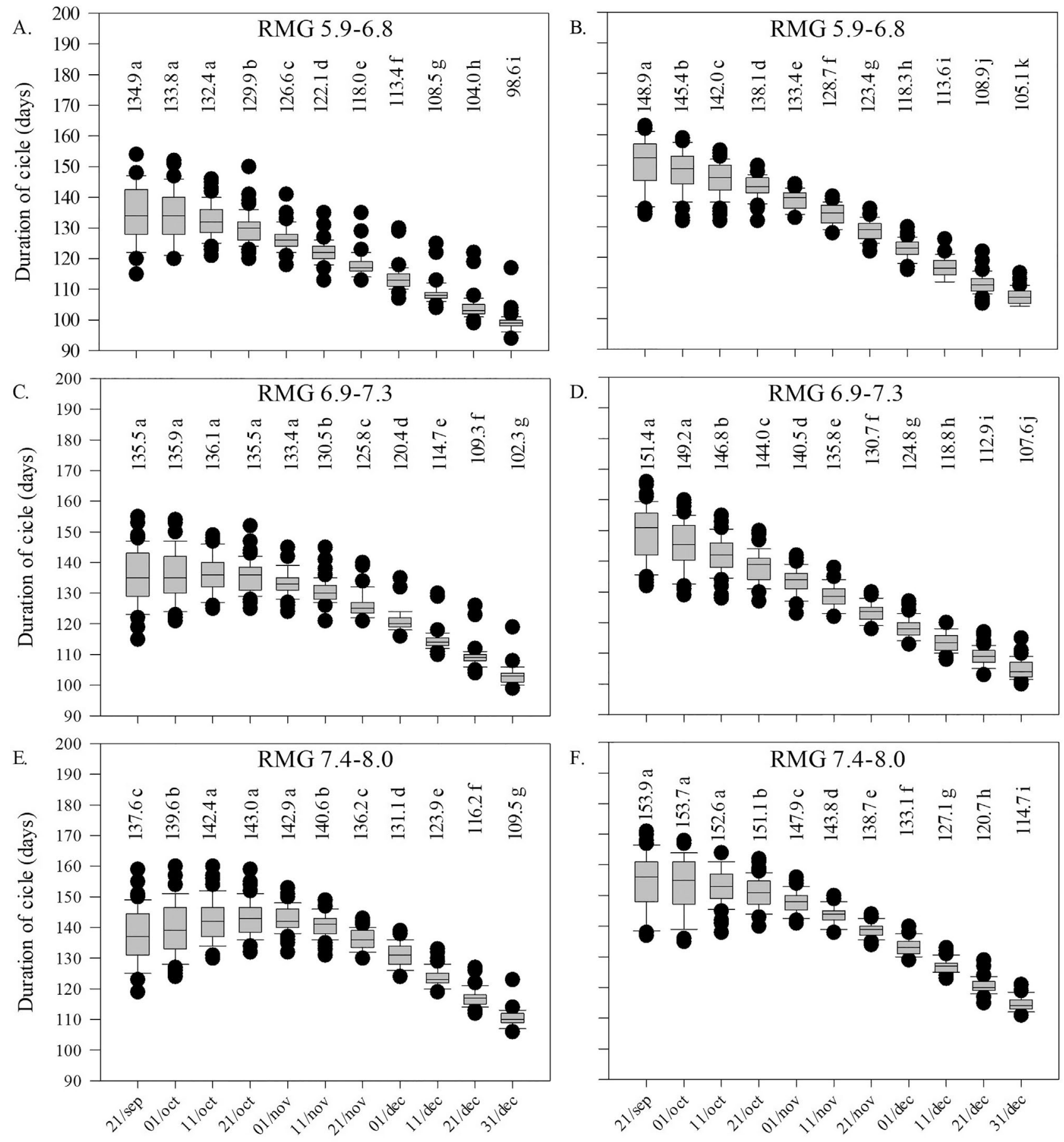

Sowing date

Sowing date

Figure 1 - Interannual variability and mean duration of the soybean development cycle, considering three relative maturity groups (RMG) in function of 11 sowing dates in Santa Maria, RS (A, C and E) and Pelotas, RS (B, D and F). Means followed by the same letters within the same subperiod do not differ between each other by Scott-Knott test at $5 \%$ probability.

expressive increase use of indeterminate growth habit cultivars has been observed, having an overlapping period between vegetative and reproductive phases and larger growth in height and node emission between R1 and R5 (Zanon et al., 2016). While there is greater competi- tion for photoassimilates between vegetative and reproductive structures, there is also a greater plasticity to overcome adverse conditions, such as the occurrence of water stress and pest damage. Notwithstanding, the obtained data can be used for all cultivars, since the 

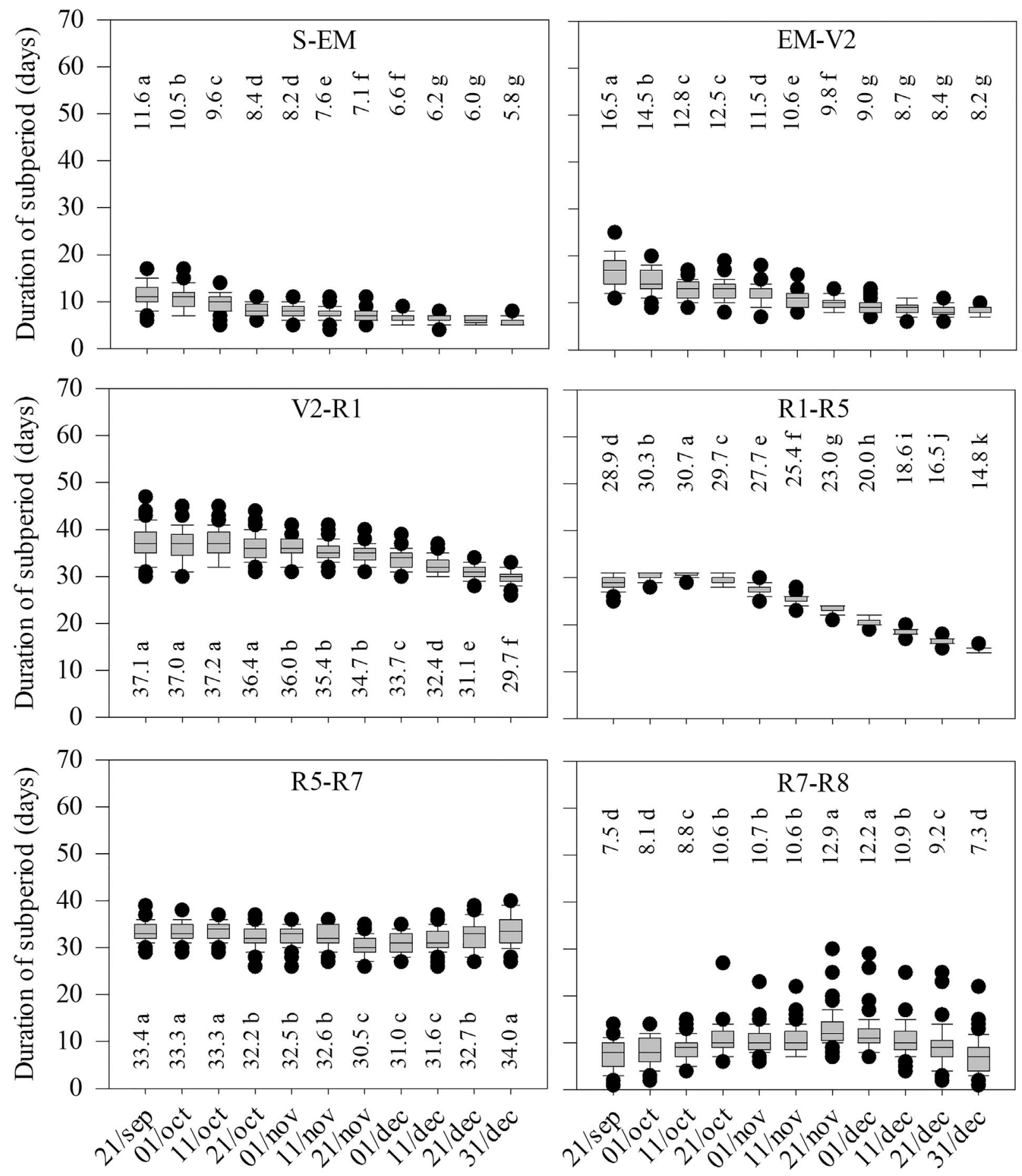

Sowing date

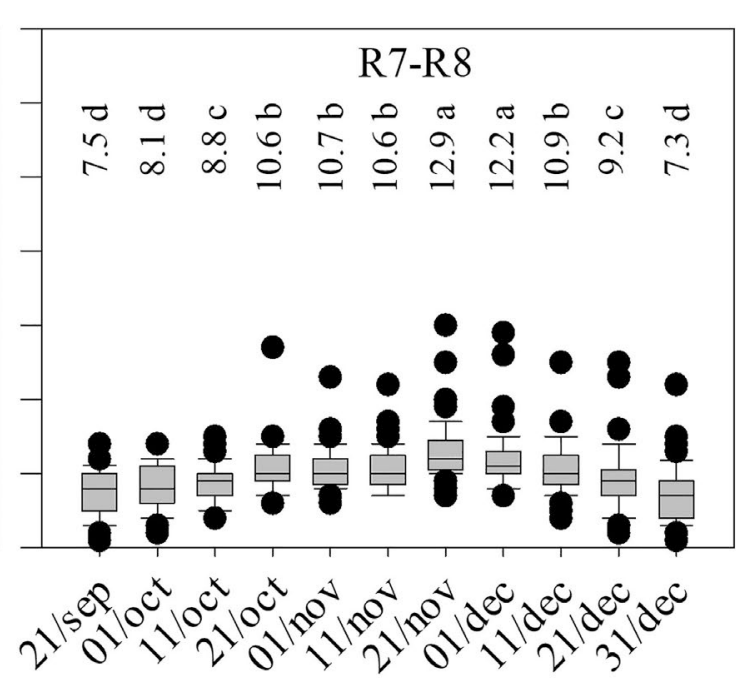

Sowing date

Figure 2 - Interannual variability and mean duration of the soybean development subperiods comprised between sowing (S), emergence (EM), first trifoliate leaf emission (V2), beginning of flowering (R1), beginning of grain filling (R5), physiological maturity (R7) and harvest maturity (R8), considering the relative maturity group (RMG) 5.9-6.8 simulated for the historical series from 1968 to 2017 in function of 11 sowing dates in Santa Maria, RS. Means followed by the same letters within the same subperiod do not differ between each other by Scott-Knott test at $5 \%$ probability.

occurrence time of V2 and R1 stages practically do not vary as a function of the soybean growth habit (Zanon et al., 2018).
The R1-R5 subperiod presented the lowest variability between years for the three RMG in the two locations, which can be verified by the small interquartile 

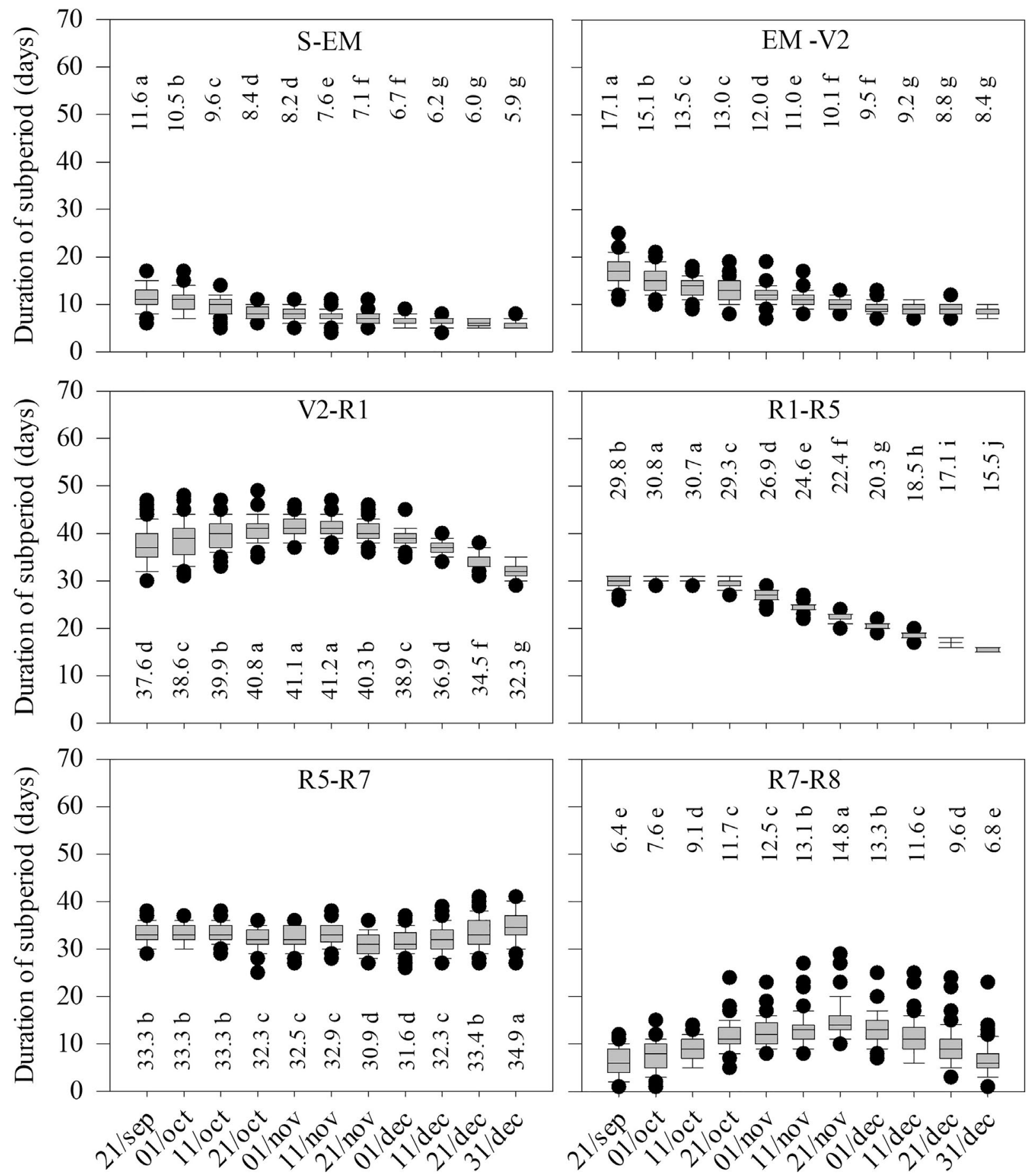

Sowing date

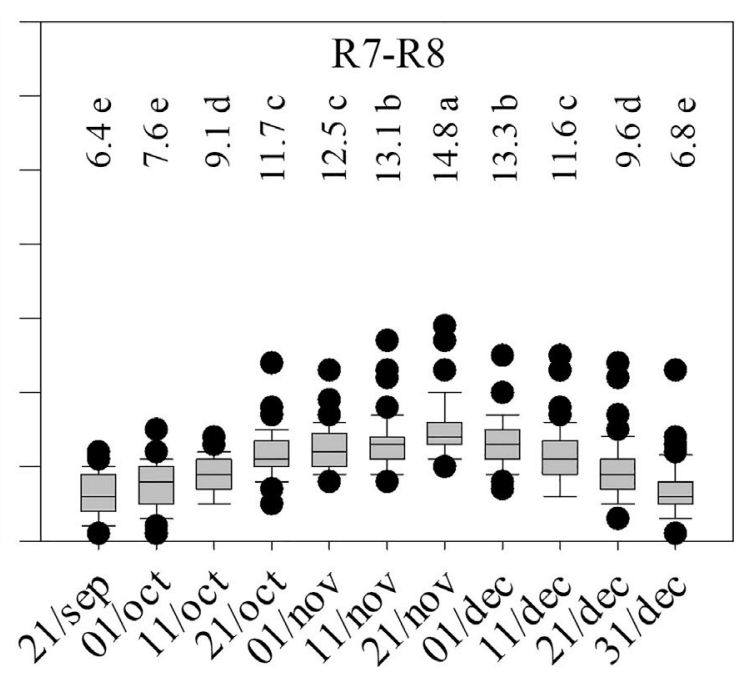

Sowing date

Figure 3 - Interannual variability and mean duration of the soybean development subperiods comprised between sowing (S), emergence (EM), first trifoliate leaf emission (V2), beginning of flowering (R1), beginning of grain filling (R5), physiological maturity (R7) and harvest maturity (R8), considering the relative maturity group (RMG) 6.9-7.3 simulated for the historical series from 1968 to 2017 in function of 11 sowing dates in Santa Maria, RS. Means followed by the same letters within the same subperiod do not differ between each other by Scott-Knott test at $5 \%$ probability.

range, indicating data that is clumped about the median (Figs. 2 to 7). This allows inferring a photoperiod control significantly greater than the air temperature over the subperiod duration, as expressed by the model of Sinclair et al. (2007). Commonly for both studied locations, marked reduction of the R1-R5 subperiod is observed for sowing dates from November 1st (Figs. 2 to 7), which is associated to decreased photoperiod (Sinclair et al., 2007) 

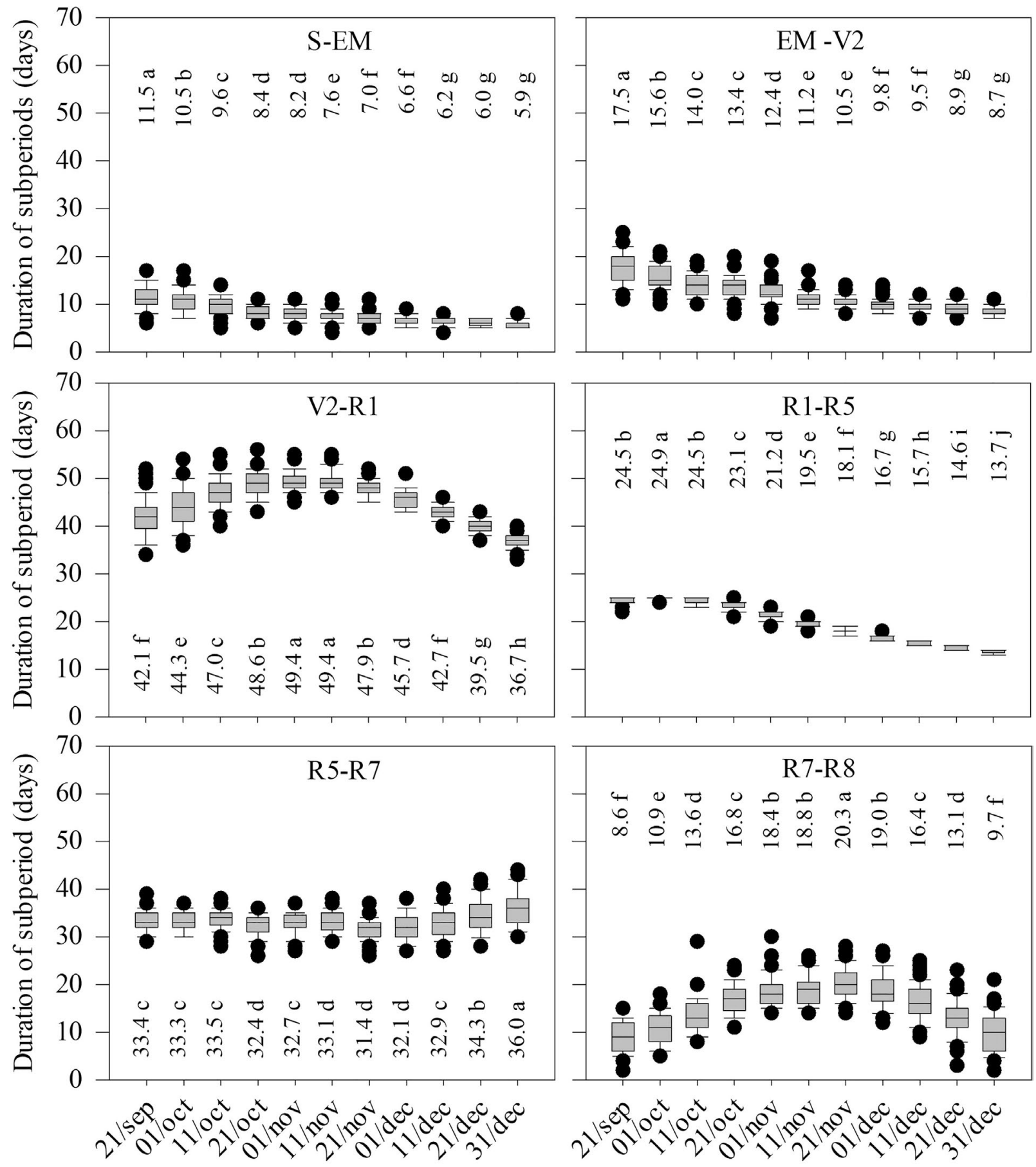

Sowing date

Sowing date

Figure 4 - Interannual variability and mean duration of the soybean development subperiods comprised between sowing (S), emergence (EM), first trifoliate leaf emission (V2), beginning of flowering (R1), beginning of grain filling (R5), physiological maturity (R7) and harvest maturity (R8), considering the relative maturity group (RMG) 7.4-8.0 simulated for the historical series from 1968 to 2017 in function of 11 sowing dates in Santa Maria, RS. Means followed by the same letters within the same subperiod do not differ between each other by Scott-Knott test at $5 \%$ probability.

and is accentuated about 10 days after the Summer solstice. Therefore, the shorter duration of this subperiod is verified for the last sowing date for both Santa Maria and Pelotas.
In addition, shorter duration of the R1-R5 subperiod was found for RMG 7.4-8.0, evidencing the greater photoperiodic induction for these cultivars. Therefore, the use of these cultivars should be considered carefully as this sub- 

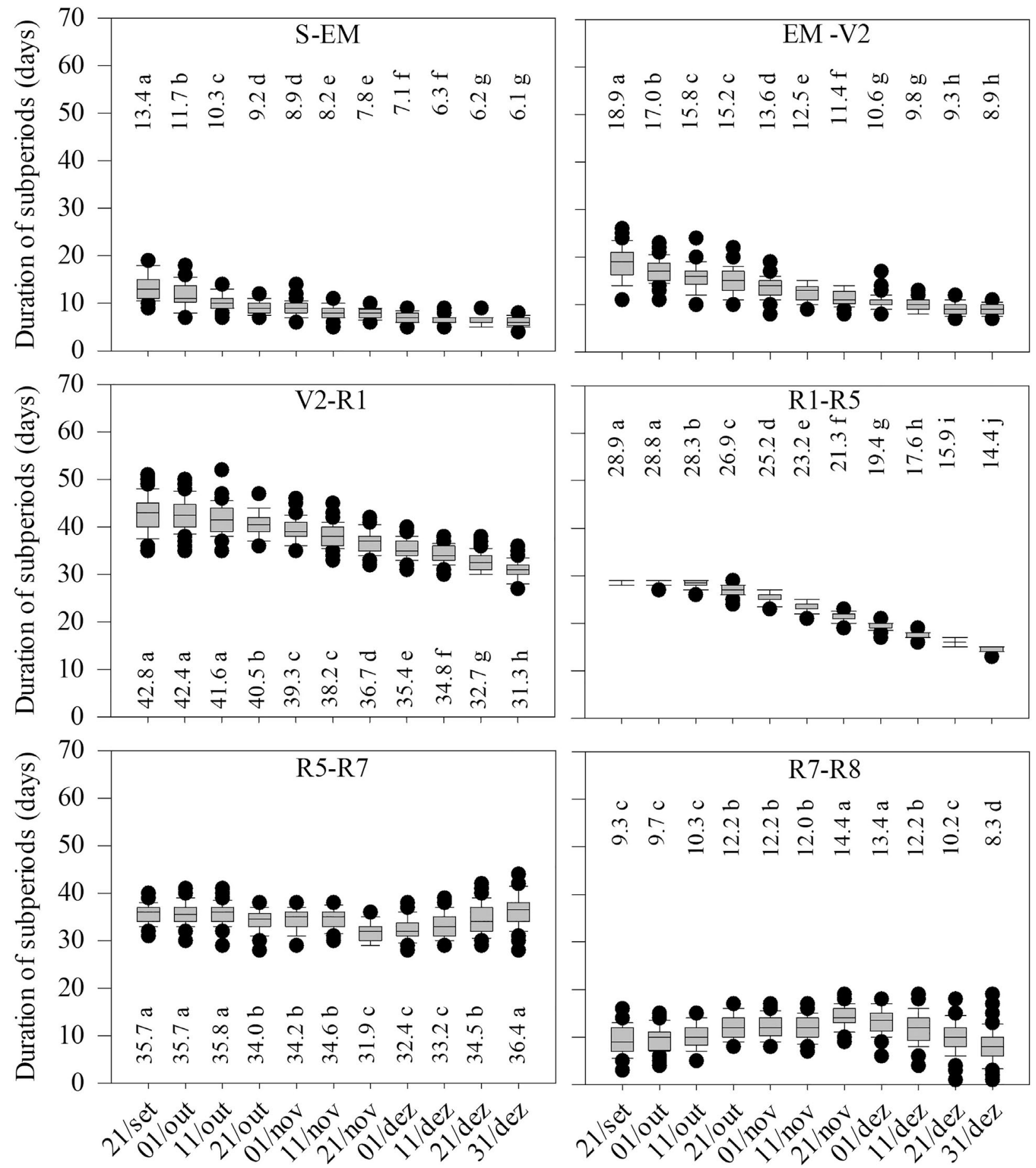

Sowing date

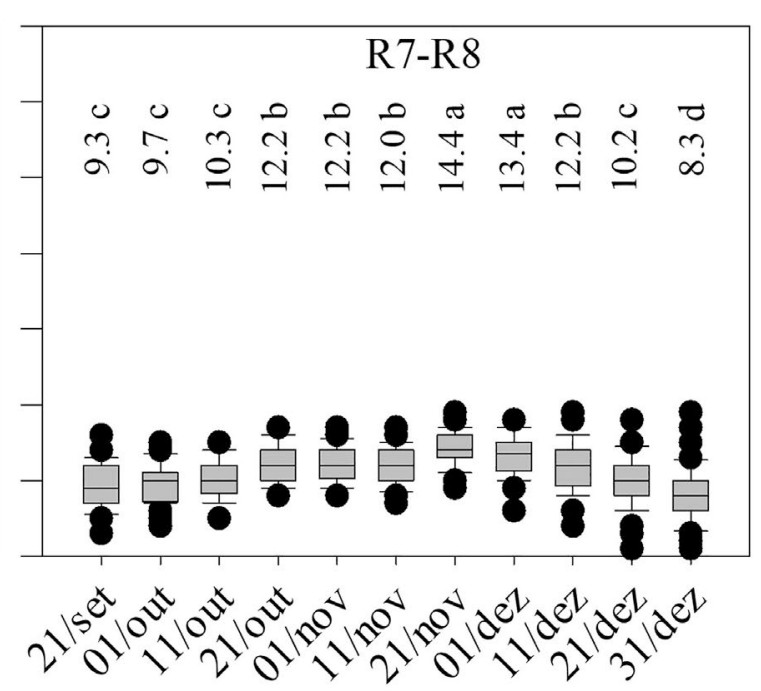

Sowing date

Figure 5 - Interannual variability and mean duration of the soybean development subperiods comprised between sowing (S), emergence (EM), first trifoliate leaf emission (V2), beginning of flowering (R1), beginning of grain filling (R5), physiological maturity (R7) and harvest maturity (R8), considering the relative maturity group (RMG) 5.9-6.8 simulated for the historical series from 1968 to 2017 in function of 11 sowing dates in Pelotas, RS. Means followed by the same letters within the same subperiod do not differ between each other by Scott-Knott test at $5 \%$ probability.

period is the most critical for stress occurrence such as water deficit (Sionit and Kramer, 1977) and water excess
(Beutler et al., 2014), mainly in lowlands (Rocha et al., 2017). 

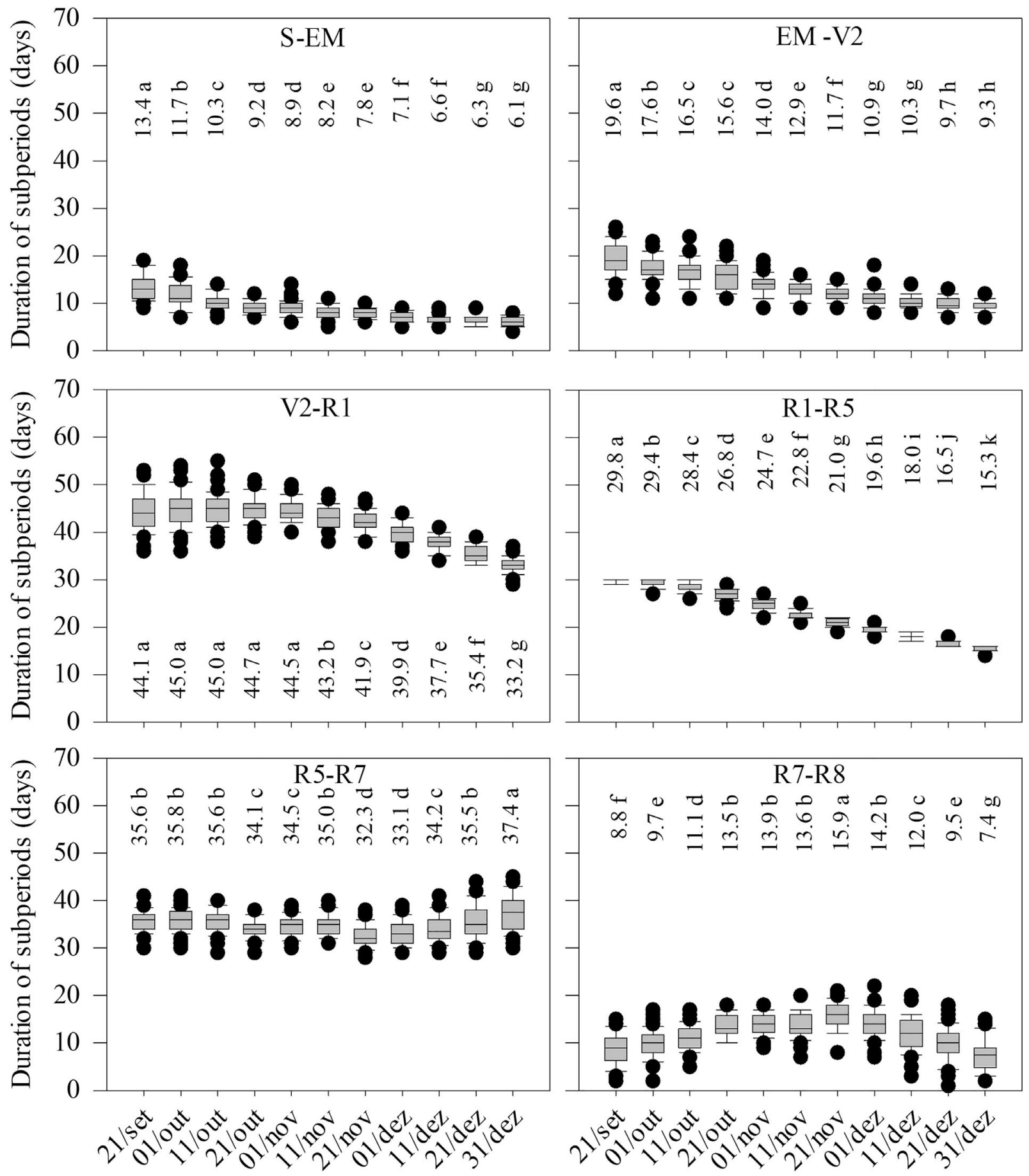

Sowing date

\section{Sowing date}

Figure 6 - Interannual variability and mean duration of the soybean development subperiods comprised between sowing (S), emergence (EM), first trifoliate leaf emission (V2), beginning of flowering (R1), beginning of grain filling (R5), physiological maturity (R7) and harvest maturity (R8), considering the relative maturity group (RMG) 6.9-7.3 simulated for the historical series from 1968 to 2017 in function of 11 sowing dates in Pelotas, RS. Means followed by the same letters within the same subperiod do not differ between each other by Scott-Knott test at $5 \%$ probability.

The R5-R7 subperiod duration exhibited the lowest variation between sowing dates, with a mean of approximately 30 to 35 days. However, there was a significant variability between years for this subperiod, which can be verified by wide range interval between the maximum and minimum values, as well as by outliers. The small varia- 

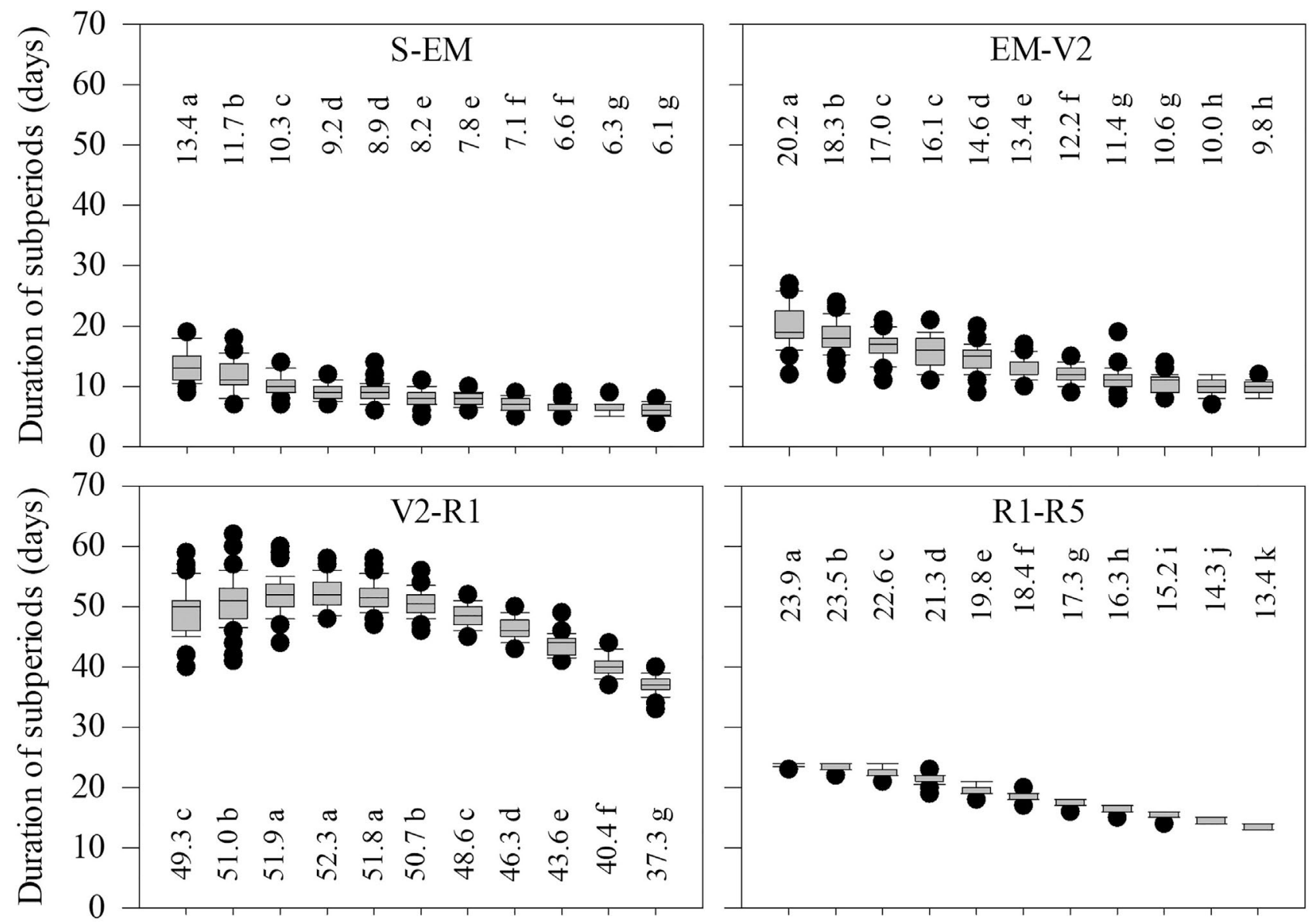

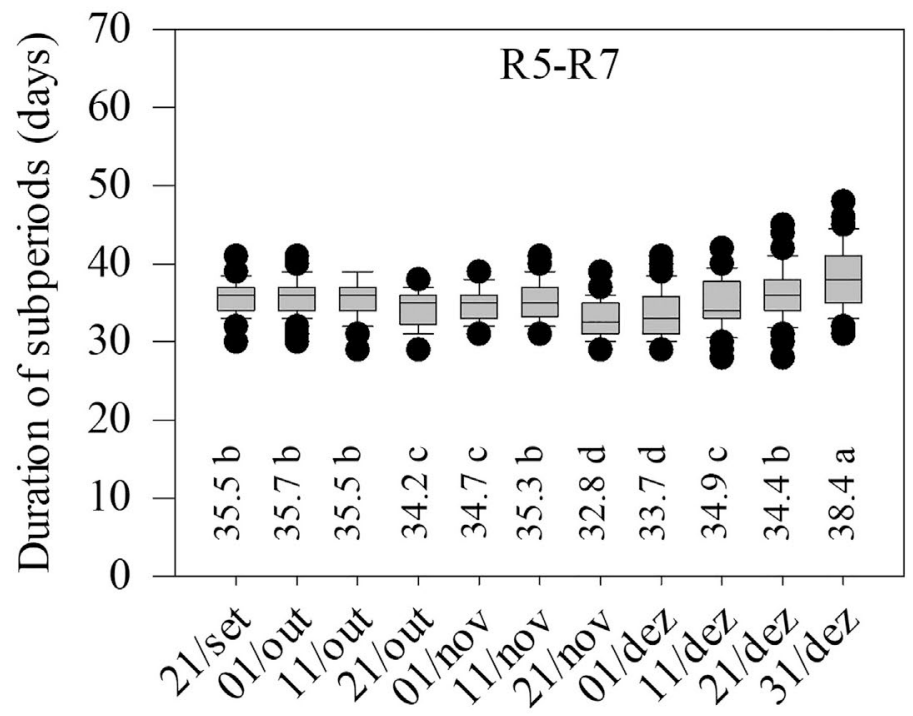

Sowing date

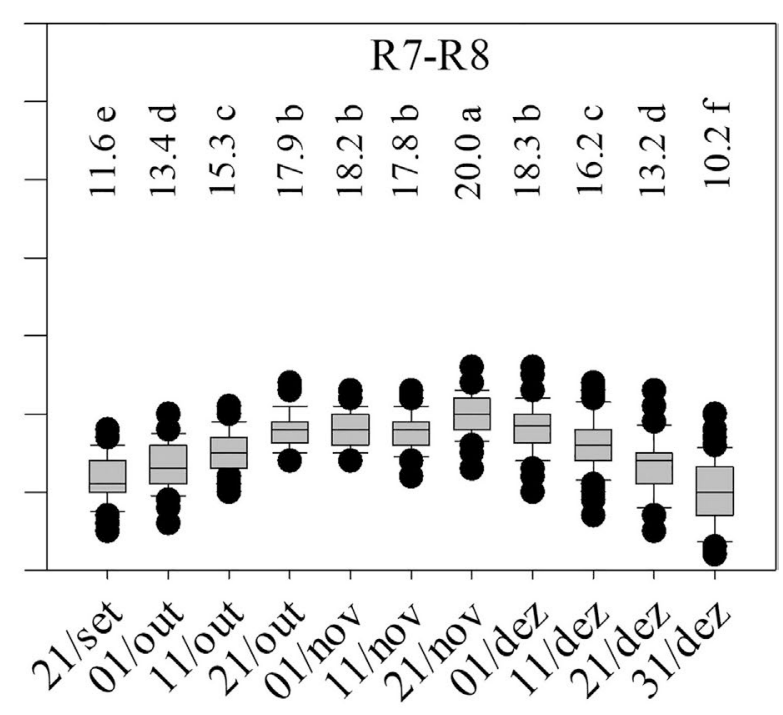

Sowing date

Figure 7 - Interannual variability and mean duration of the soybean development subperiods comprised between sowing (S), emergence (EM), first trifoliate leaf emission (V2), beginning of flowering (R1), beginning of grain filling (R5), physiological maturity (R7) and harvest maturity (R8), considering the relative maturity group (RMG) 7.4-8.0 simulated for the historical series from 1968 to 2017 in function of 11 sowing dates in Pelotas, RS. Means followed by the same letters within the same subperiod do not differ between each other by Scott-Knott test at $5 \%$ probability.

bility verified between sowing dates is due to a slight trend of longer duration for the last sowing dates (Figs. 2 to 7 ) due to the lower thermal availability, typical of March and April in relation to Summer months. 
Regarding the R7-R8 subperiod, there was a longer duration for the sowing dates near November. A great variability of the R7-R8 subperiod duration between years was found, regardless of RMG and the growing location. There were many extreme values and a great interquartile range (Figs. 2 to 7). This variability was also reported by Zanon et al. (2015) in different sowing dates.

According to Rocha et al. (2017), soybean development in function of upland or lowland cultivation has small differences. Besides the upland environment where soybean is commonly grown, the results obtained in our study indicate the amplitude of the development cycle duration for practically the entire cultivated area under lowland soybean, since they consider more distinct climatic conditions in the southern half of Rio Grande do Sul.

\section{Conclusions}

The soybean development cycle duration is greater in Pelotas in comparison to Santa Maria due to lower thermal availability and longer photoperiod near the Summer solstice.

Regardless of the growing location, greater cultivar relative maturity groups is associated with longer development cycle.

The vegetative phase duration is reduced in early sowing dates due to exposure to short photoperiods, mainly for greater relative maturity groups cultivars.

The R1-R5 subperiod duration is decreasing from October to December and is related to decreased photoperiod at later sowing dates.

\section{Acknowledgments}

The authors are thankful to the National Council for Scientific and Technological Development $(\mathrm{CNPq})$ and the Coordination for the Improvement of Higher Education Personnel (CAPES) for granting the scholarships respectively of research productivity and doctorate degree.

\section{References}

ALVARES, C.A.; STAPE, J.L.; SENTELHAS, P.C.; GONÇALVES, J.L.M; SPAROVEK, G. Köppen's climate classification map for Brazil. Meteorologische Zeitschrift, v. 22 , n. 6 , p. $711-728,2013$

BEUTLER, A.N.; GIACOMELI, R.; ALBERTO, C.M.; SILVA, V.N.; DA SILVA NETO, G.F.; MACHADO, G.A.; SANTOS, A.T.L. Soil hydric excess and soybean yield and development in Brazil. Australian Journal of Crop Science, v. 8, n. 10, p. 1461-1466, 2014.

BORTOLUZZI, M.P.; HELDWEIN, A.B.; TRENTIN, R.; NIED, A.H.; SILVA, J.R.; ROCHA, L. Adjustment of probability functions to water excess and deficit in soybeans cultivated in lowland soils. Irriga, v. 25, n. 2, p. 402-419, 2020a.
BORTOLUZZI, M.P.; HELDWEIN, A.B.; TRENTIN, R.; MALDANER, I.C.; SILVA, J.R. Risk of occurrence of water deficit in soybean cultivated in lowland soils. Earth Interactions, v. 24, n. 4, p. 1-9, 2020b.

BURIOL, G.A.; ESTEFANEL, V.; HELDWEIN, A.B.; PRESTES, S.D.; HORN, J.F.C. Estimativa da radiação solar global a partir dos dados de insolação, para Santa Maria, RS. Ciência Rural, v.42, n.9, p.1563-1567, 2012.

CARPENTIERI-PÍPOLO, V.; ALMEIDA, L.A.DE; KIIHL, R.A. DE S. Inheritance of a long juvenile period under short-day conditions in soybean. Genetics and Molecular Biology, v. 25, n. 4, p. 463-469, 2002.

CERA, J.C.; STRECK, N.A.; YANG, H.; ZANON, A.J.; PAULA, G.M. DE; LAGO, I. Extending the evaluation of the SoySim model to soybean cultivars with high maturation groups. Field Crops Research, v. 201, p. 162-174, 2017.

KIESLING, T.C. Calculation of the length of the day. Agronomy Journal, v. 74, n. 4, p. 758-759, 1982.

MARTORANO, L.G.; BERGAMASCHI, H. FARIA, R.T.; DALMAGO, G.A. Decision strategies for soil water estimations in soybean crops subjected to no-tillage and conventional systems, in Brazil. In: Manish Kumar. (Org.). Problems, Perspectives and Challenges of Agricultural Water Management. Rijeka: InTech - Open Access Publisher, p. 439-453, 2012.

ROCHA, T.S.M.; STRECK, N.A.; ZANON, A.J.; MARCOLIN, E.; PETRY, M.T.; TAGLIAPIETRA, E.L.; BARLEST, D.; BEXAIRA, K.P. Performance of soybean in hydromorphic and nonhydromorphic soil under irrigated or rainfed conditions. Pesquisa Agropecuária Brasileira, v. 52, n. 5, p. 293-302, 2017.

SCHNEIDER, F.M.; BURIOL, G.A.; HELDWEIN, A.B.; MANFRON, P.A.; SACCOL, A.V. ESTEFANEL, V. Temperatura base e soma térmica do subperíodo semeadura emergência para algumas cultivares de soja (Glycine max (L.) Merrill). Revista do Centro de Ciências Rurais, v. 17, n. 4, p. 299-308, 1987.

SCOTT, A.J.; KNOTT, M. A Cluster analysis method for grouping means in the analysis of variance. Biometrics, v. 30, n. 3, p. 507-512, 1974.

SETIYONO, T.D.; WEISS, A.; SPECHTA, J.; BASTIDASA, A.M.; CASSMANA, K.G.; DOBERMANNA, A. Understanding and modeling the effect of temperature and day length on soybean phenology under high-yield conditions. Field Crops Research, v. 100, n. 2-3, p. 257-271, 2007.

SETIYONO, T.D.; CASSMANA, K.G.; SPECHTA, J.E.; DOBERMANNB, A.; WEISSC, A. YANGD, H.; CONLEYE, S.P.; ROBINSONF, A.P.; PEDERSENG, P.; DE BRUINH, J.D. Simulation of soybean growth and yield in near-optimal growth conditions. Field Crops Research, v. 119, n. 1, p. 161-174, 2010.

SINCLAIR, T.R. Water and nitrogen limitations in soybean grain productivity. I. Model development. Field Crops Research, v. 15, n. 2, p. 125-141, 1986.

SINCLAIR, T.R.; KITANI, S.; HINSON, K.; BRUNIARD, J.; HORIE, T. Soybean flowering date: linear and logistic models based on temperature and photoperiod. Crop Science, v. 31, n. 3, p. 786-790, 1991.

SINCLAIR, T.R.; SALADO-NAVARRO, L.R.; SALAS, G.; PURCELLD, L.C. Soybean yields and soil water status in 
Argentina: Simulation analysis. Agricultural Systems, v. 94, n. 2, p. 471-477, 2007.

SIONIT, N.; KRAMER, P.J. Effect of water stress during different stages of growth of soybean. Agronomy Journal, v. 69 , n. 2, p. 274-278, 1977.

STEINMETZ, S.; ASSIS, F.N. Estimativa da radiação solar global a partir da insolação na região de Pelotas, Rio Grande do Sul. Revista Agropecuária de Clima Temperado, v. 2, n. 1, p. 77-85, 1999.

STRECK, N.A.; PAULA, G.M. DE; CAMERA, C.; MENEZES, N.L. DE; LAGO, I. Estimativa do plastocrono em cultivares de soja. Bragantia, v. 67, n. 1, p. 67-73, 2008.

STRECK, N.A.; PAULA, G.M.; OLIVEIRA, F.B.; SCHWANTES, A.P.; MENEZES, N.L. de. Improving node number simulation in soybean. Pesquisa Agropecuária Brasileira, v. 44, n. 1, p. 661-668, 2009.

TRENTIN, R.; HELDWEIN, A.B.; STRECK, N.A.; TRENTIN, G.; SILVA, J.C. da Subperíodos fenológicos e ciclo da soja conforme grupos de maturidade e datas de semeadura. Pesquisa Agropecuária Brasileira, v. 48, n. 7, p. 703-713, 2013.

ZANON, A.J.; WINCK, J.E.M.; STRECK, N.A.; ROCHA, T.S.M. DA, CERA, J.C.; RICHTER, G L.; LAGO, I.;
SANTOS, P.M. DOS; MACIEL, L.R.; GUEDES, J.V.C.; MARCHESAN, E. Development of soybean cultivars as a function of maturation group and growth type in high lands and in lowlands. Bragantia, v. 74, n. 4, p. 400-411. 2015.

ZANON, A.J.; STRECK, N.A.; ROCHA, T.S.M. DA; ALBERTO, C.M.; BARTZ, A.C.; PAULA, G.M. DE; TOMIOZZO, R.; COSTA, L.C. DA; FENSTERSEIFER, C.A.; TAGLIAPIETRA, E.L.; CARDOSO, A.P.; WEBER, P.S.; BEXAIRA, K.P. Growth habit effect on development of modern soybean cultivars after beginning of bloom in Rio Grande do Sul. Bragantia, v. 75, n. 4, p. 445-458, 2016.

ZANON A.J.; SILVA, M.R. DA; TAGLIAPIETRA, E.L.; CERA, J.C.; BEXAIRA, K.P.; RICHTER, G.L.; JUNIOR, A.J.D.; ROCHA, T.S.M. DA; WEBER, P.S.; STRECK, N.A. Ecofisiologia da Soja: Visando Altas Produtividades. Santa Maria: Palloti, 136 p., 2018.

License information: This is an open-access article distributed under the terms of the Creative Commons Attribution License (type CC-BY), which permits unrestricted use, distribution and reproduction in any medium, provided the original article is properly cited. 